\title{
THE VOYAGE OF THE GELDERLAND
}

\section{Johannes Vrugtman*}

In midsummer dawn comes early in the Netherlands and normally the sun would have been well above the horizon before the first stirrings of activity at the Willemsoord naval base at Nieuwediep. However, on this 15 th day of July 1900 things were different. It was the day on which the sleek white shape at the outfitting dock would be commissioned and formally join the fleet. As a result work details were busy from early light to put the finishing touches to the grandstand and to see that everything was shipshape.

Ship commissioning ceremonies are important and festive occasions for navies everywhere, but for Her Royal Netherlands Majesty's Navy this was a more than usually significant event. To the navy and the government the day was a high point in the long struggle to rebuild the fleet during a time when the long drawn out war in Achin on the island of Sumatra had tended to absorb all funds available for defense. Later in the day the ship would be taken over from the builder, the Fijenoord yard at Rotterdam, designated the HMS Gelderland, and placed under the command of Kapitein ter Zee (captain) Jacques Henri Leonard Jean, Baron Zweerts de Landas Wijborgh.

The Gelderland was the latest and most advanced of a series of armoured deck ships considered by many to be of an important new class. Named after various provinces of the Netherlands the class included besides the Gelderland the Holland, Zeeland, Friesland, Utrecht, and Noord Brabant. The 311 feet long 4,000 ton Gelderland combined in her design great firepower, armour protection, and speed. Her armament included two $15 \mathrm{cM}$, six $12 \mathrm{cM}$, and four $7.5 \mathrm{cM}$ cannon,

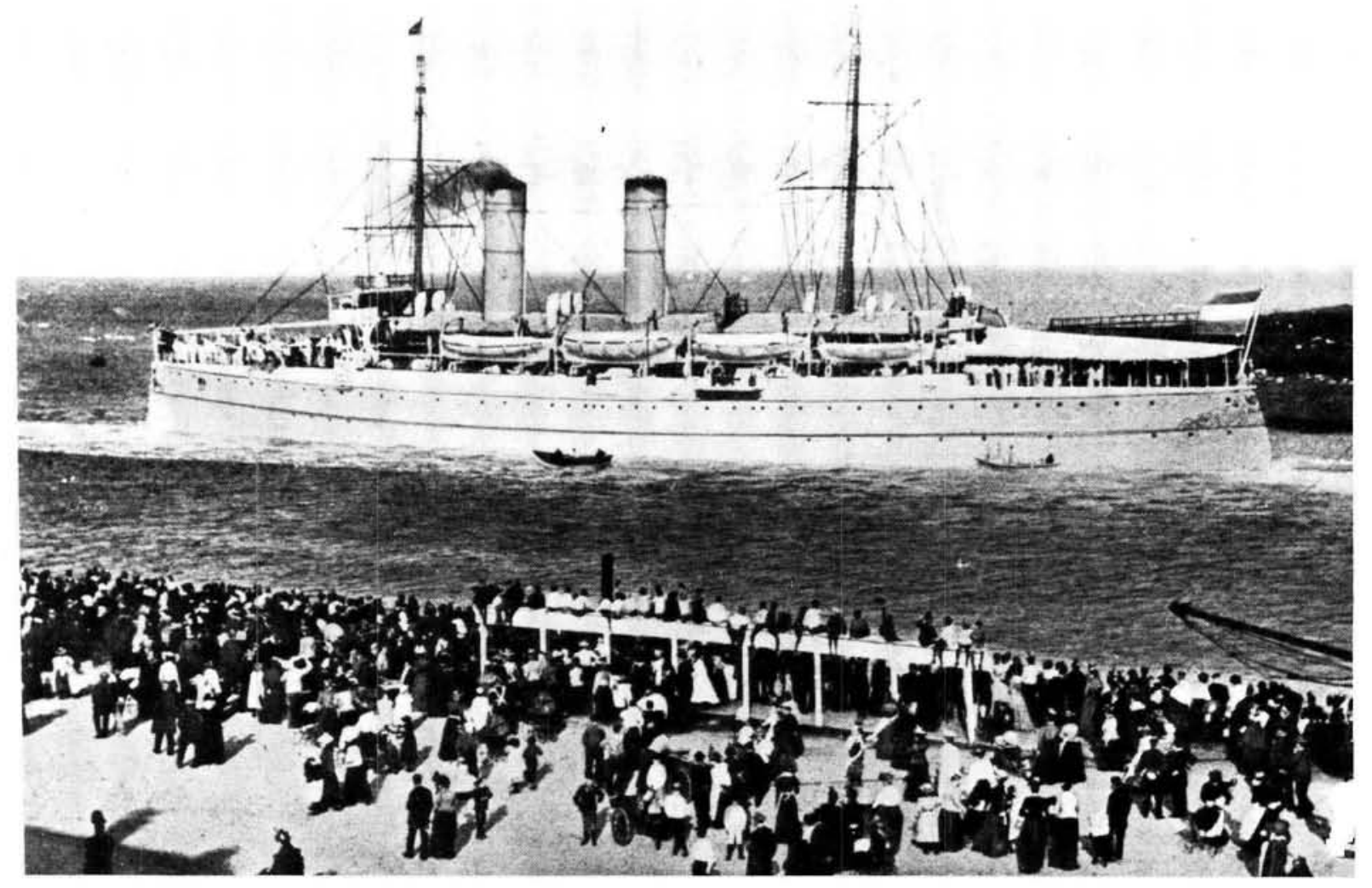

The Gelderland, armored deck ship belonging to her Royal Netherlands Majesty's Navy, on which President Kruger of the South African Republic departed from Lorenço Marques (Maputo) for Europe. 
numerous smaller pieces among which four 3.7 $\mathrm{CM}$ rapid firing (revolver) guns, a bow-mounted torpedo tube and three deck-mounted torpedo launchers. Her $5 \mathrm{cM}$ top deck armour and refined compartmentation made for better damage control and survivability. However, her most distinguishing feature was a speed of just over 20 knots, almost unheard of at that time for a ship of her type. The above features made her an ideal raider, a wolf among the sheep. Her speed put her on a par with destroyers, which she easily outgunned, while she could outrun heavier ships. For her day the Gelderland represented the type of threat that the German Pocket Battleships were to pose in World War II.

Through the entire morning carriages delivered dignitaries to the site of the ceremonies. Chief among the VIPs were representatives of the Navy Ministry, which would take formal delivery of the ship, members of the States General, and the Navy Chief of Staff. The press, to include the wire services were also represented. As usual in those days before electronic speech amplification only those in the immediate vicinity of the speakers platform could hear what was being said. Everyone else used the time to look the ship over and keep an eye on the companionway to see when the dignitaries would board the ship where the actual commissioning would take place. Finally the top-hatted and morning-coated dignitaries went aboard where the 310 men ship's complement was drawn up in formation. Now all that remained to be done was for the ship's commandant to address his men and to order the jack, pennant, and national flag raised to signify the ship's official entry into the fleet. With this done under thunderous huzzas and, with the playing by the Marine band of the National Anthem, the ceremonies were over.

On 22 August the Gelderland departed the naval base at the entrance to the Zuiderzee and set out on her maiden voyage, which was to take her to the East Indies for a projected two and a half year's tour of duty. Before heading south the ship stopped at Vlissingen (Flushing) for three days compass compensation and final instrument checks. On 25 August the ship left Vlissingen and set course for the Strait of Gibraltar. No attempt was made to achieve great speed as the principal task at hand was to have the crew familiarize itself thoroughly with ship's equipment and characteristics. One of her characteristics showed up when upon entering the Mediterranean head seas were encountered, the Gelderland was a 'pitcher', something which could have been expected from a ship with her fine lines and heavy superstruc ture.

After a bunker stop at Algiers the ship reached Port Said on 10 September. There a Suez Canal pilot was taken aboard as well as a powerful searchlight for use during night travel. The passage through the canal and the Red Sea brought to light a problem that had been foreseen by insiders, but which had been swept under the rug for political reasons. The Gelderland represented the latest in naval technology, but such technology does not come cheaply. Her construction cost had been high and her operating cost was expected to be high also if only because of the expected voracious appetite of her 12 Yarrow-type boilers which permitted her triple expansion steam engines to develop almost 10000 shaft horse power. Aware that the opposition in the States General, which had objected to the construction cost of the vessel, would certainly use high operating cost as added ammunition, the Navy Minister was at great pains to keep projected operating cost down. One area of conservation had been the manning scale, which had been pared to the bone. Knowledgeable people warned that the ship's complement would prove too small especially in the engine room area where operations in the tropics would require shorter working hours and more frequent relief of the men. The government, aware of the problem, had secretly decided to hire Lascars as firemen as soon as the ship reached the East Indies, but was not about to let this information reach the opposition benches. The government carried the day in the debates in the Lower House, but undoubtedly impressed upon the ship's commandant the necessity of reaching his destination with the number of men authorized. Upon entering the Red Sea daytime temperatures in the stoke hold rose to $125^{\circ} \mathrm{F}$ and over. Men from the temperate zones have difficulty living under such temperatures let alone work. As a result the men had to be relieved frequently and some had to be revived in the sick bay after passing out. It took heroic measures on the part of the medical officer to keep from losing anyone to heat stroke. On 14 September the Tropic of Cancer was passed, normally a reason for rejoicing, as it marked the beginning of tropical pay, a 25 percent increase across the board. This time the day passed soberly as the mood of the engine room men ranged from sullen to rebellious, which had its effect on the whole ship's complement. During the night of 16 September a state of near mutiny was reached. The stokers were unable or unwilling to keep up 
steam and the ship was forced to drop anchor. Seeing that neither reasoning nor threats availed the commandant capitulated and assigned personnel from other departments to augment the engine room crew. (The matter did not rest there, however. Later three firemen were courtmartialed for insubordination.)

Two days later the ship reached the Strait of Bab-el-Mandeb and anchored off the island of Perim to take on bunker coal. The local coaling station proved to be out of Cardiff coal because of the heavy demands made by ships en route to the Boxer Rebellion in China. As a collier was expected the next day the commandant decided to stay at Perim rather than to go to Aden. The delay gave the officers and noncoms a welcome chance to stretch their legs ashore. The lower ranks were not permitted ashore and, as things turned out, did not get liberty until late November. Perim was not exactly an inviting place. It appeared to be a rock without signs of vegetation. There was a small fort and a coal pier, but no town. The island's one redeeming feature was that it boasted a hotel, the Oriental, which served cold beer. The Oriental's bar was logically the locus of all gossip and of stories about the wars in China and South Africa. One bit of news of interest to the men of the Gelderland was that a British warship that had preceded them through the Red Sea had actually lost two stokers to heat stroke.

On 19 September bunkering commenced and on the 20th the ship would have gotten underway for the Strait of Malacca if word had not been received from The Hague that the next destination was to be Lorenço Marquez in what was then the Portuguese East African colony of Mozambique. At Lorenço Marquez the commandant was to place his ship at the disposal of President Kruger of the South African Republic, or Transvaal, as it was commonly called.

Since October of the previous year Transvaal and its sister republic the Orange Free State had been at war with Great Britain. At first the Boer Commandos had set the inexperienced British troops on their heels, just as they had done in the first Anglo-Boer War of 1880-81. However, since the arrival of heavy reinforcements and new leadership in the persons of Field Marshal Roberts and his Chief of Staff Kitchener, the hero of Omdurman, the Boer position had deteriorated rapidly. By September 1900 Kruger, the spiritual leader of the Boers, had been forced to leave the country and seek asylum in Portuguese Mozambique.

The war in South Africa had been front page news in the western world from the start and had caught the public's imagination. The very disparity in power between the antagonists had given the war a romantic touch and had caused volunteers from many nations to join the underdogs. Fairly or not world opinion held by and large that the British action in South Africa constituted an unwarranted attack by a world power on two small nations for the purpose of capturing their mineral resources. Many regarded the war in fact as a continuation by other means of the political legerdemain by which Great Britain had earlier gained control over the Kimberley diamond fields.

Few of the men of the Gelderland, if asked, would have professed complete neutrality in the conflict. More even than citizens of other western countries the Dutch had reasons to sympathize with the Boers. After all many of the forebears of the Boers had come originally from the Low Countries and their official, if not the spoken, language was Dutch. Also there were many economic ties between the Netherlands and the Boer republics. Thus the Dutch public identified very much with the Boer cause. This state of affairs should not hide the fact that more than geographic distance separated The Hague from Pretoria. At the turn of the century the Netherlands was a modern nation with a well-developed economy and a literate population. Its views in regard to other races, though not yet enlightened by today's standards, had come a long way since the days of the East and West India Companies. In religion the rigid dogmatism of the days of the Reformation and the war of independence had long since been softened and humanized. In contrast the Boer republics were economically backward and the white portion of their populations had lived in isolation from the mainstream of western thought for three generations. It may even be argued that the isolation had begun when the first 'free burghers' had taken to the land for purposes other than providing fresh meat and produce for the fleets of the 'Vereenigde Oost Indische Compagnie', the East India company that had first settled the Cape of Good Hope. The churches in South Africa had remained essentially Bezan Calvinist or ContraRemonstrant, that is hard line fundamentalist. The average Boer's world was defined by family, church, land, and (usually hostile) natives. This world is what he knew and loved and was determined to defend at all cost. That their 
countries' mineral wealth and its economic and geopolitical implications had doomed that world seemed to have been understood by few. However, none of the foregoing considerations would have meant much to the men of the Gelderland. To them the point was that the British navy controlled the waters around South Africa and that they were to snatch President Kruger from under its nose.

It was generally assumed that the president, who had enjoyed excellent relations with Germany and the Netherlands since his accession to the post in 1883, might want to go to either of these countries. While speculation went on aboard the Gelderland the ship remained at Perim, a British-controlled island, until 27 September when definitive orders were received to proceed with all deliberate speed to Lorenço Marquez, take President Kruger aboard, then sail for Europe. After a short stop at Aden to pick up charts for the East African coastal waters the Gelderland set course for the Mozambique Channel. During the two weeks it took to make the journey tension aboard slowly mounted. The ship was made combat ready and the frequent alerts kept everyone on tenderhooks. To make matters worse a quartering swell caused the ship to labour heavily and forced it to 'button up', which in these tropical latitudes added to everyone's discomfort. The usual festivities attending the passing of the Equator were dispensed with; no one was in the mood for horseplay. On 12 October the Gelderlandentered Delagoa Bay, the harbour of Lorenco Marquez, finding a four ship British squadron at anchor there. There were also several Portuguese naval vessels at anchor, but for these few on the Gelderland had eyes, even though the latter ships observed the amenities by saluting the newcomer. The British ships lay silent.

Although Lorenço Marquez (now Maputo) was the capital of a Portuguese colony the Portuguese themselves were little in evidence. Besides the natives the town was crowded with peoples from many countries with Boers and Netherlanders predominant. Being the terminus of the PretoriaDelagoa Bay railroad, which was run by a Netherlands company, and was still largely free from British control, the town had until recently handled most of the Transvaal imports. This traffic alone had brought in many foreigners, primarily Germans and Netherlanders, and smaller numbers of French, Russians, and Americans. To add to the international flavour there were some 800 interned Boer soldiers and a smaller number of interned foreign volunteers. Most of the latter two groups had crossed the Transvaal border after the fall of Pretoria in early June. The internees were quartered in an old fort in the foothills above the town. Most of the men were poorly dressed as they had come in with only the clothes on their backs. The Portuguese had been hard put to handle the influx and the best they could do was to provide temporary housing and food. For shelter most of the internees had to make do with what tentage was available and that was deteriorating rapidly in the local climate. Although at that time of the year, the days are hot in Lorenço Marquez the nights are chilly, especially in the foothills, which made the lack of blankets for the internees felt strongly. To add to the discomfort, and not that of the internees alone, frequent strong land winds raised clouds of fine swirling sand. This kind of sand is particularly hard on the eyes and many of the people in town seemed to have permanently inflamed eyelids. The same eye irritant was found on the veld and was presumably the cause of the rheumy look of Kruger's eyes in photos published of him.

Now that the war seemed to be lost - it actually lasted for another year and a half - many of the foreign volunteers were beginning to consider the

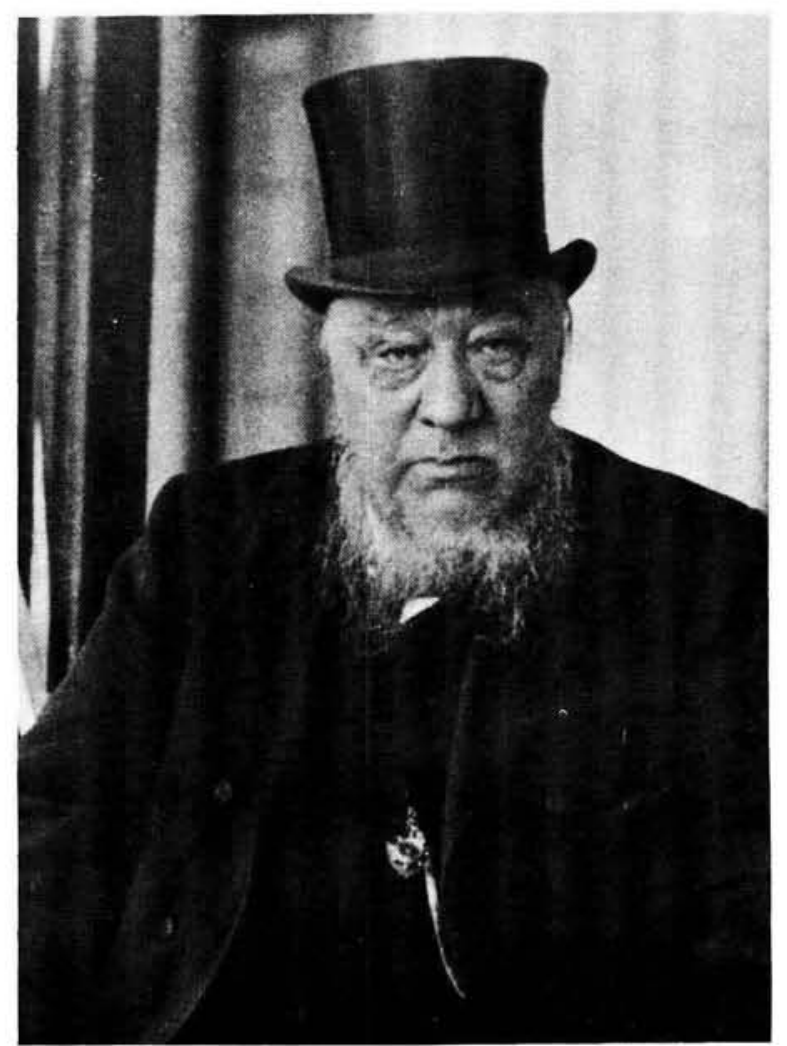

President Stephanus Johannes Paulus Kruger. 
standing British offer of a bonus of 10 pounds Sterling and free passage home on promise of staying out of the conflict from then on. Aside from the lack of adequate housing the life of the internees was not too bad. They had the freedom of the town and were required to report in only once every twenty-four hours. A number of the Boers and Netherlands volunteers took the opportunity to visit the Gelderland, exchange gossip with the crew and mooch a cigar or a drink. One day it was noticed that the internees suddenly looked much better dressed. It turned out that a trainload of captured British equipment had arrived and that the Netherlands Consul had distributed the clothing items included therein to the internees. It was an incongruous sight, all those Boers in British field uniforms.

On 18 October word was received that Queen Wilhelmina of the Netherlands was betrothed to the Duke of Mecklenburg-Schwerin, later to become the Prince-Consort Henry. Thus Friday the 19th was declared an official holiday with speeches and extra grog rations (gin in the Netherlands navy of the time) for all hands. Mr. Pot, the busy Netherlands Consul, let it be known that President Kruger, who was the guest of the Portuguese Governor, would board the Gelderland on the 19th and was to be taken to Marseilles. This was news to the men if not to the commandant and his staff.

Officially Kruger was to go to Europe for a sixty-day period of rest and recuperation. Although there was some truth in that announcement it was more his age (75) than his health that had prompted the action. If he had been twenty years younger, he would undoubtedly have taken the field to lead the commandos. As things stood it had been concluded in meetings held in August that he could do the Boer cause more good by exploiting his relations with the Kaiser and with the young queen of the Netherlands. The influence of his immense popularity with the European masses was not overlooked either. In Kruger's absence Vice President Schalk-Burger was designated Acting President. A rumour did the rounds on the Gelderland that Kruger objected to boarding the ship on a Friday as he considered that an unlucky day. The source of this rumour was not difficult to divine as the idea of Friday being an unlucky day is an old sailor's superstition. At any rate the president and his party did come on board during the early morning hours of Friday the 19th of October 1900. The timing of arrival surprised everyone, even the commandant, who was still abed. The desire to foil any possible plans of British agents may have had something to do with the surreptitious move.

Besides the president, the party consisted of only four people: Dr. Heijmans, the president's personal physician; Mr. Bredel (?), the former Chief of Police of Pretoria; a Mr. Eloff, who acted as Kruger's private secretary and was his grandson by marriage; and a valet named Happé, a Netherlander from Amsterdam.

To the men of the Gelderland Stephanus Johannes Paulus Kruger, President of the South African Republic, affectionately known to his people as 'Oom Paul', looked exactly like his pictures. A heavy set man, who from a distance did not look his six feet, he had a large round face with watery blue eyes surrounded by a beard that left his chin and mouth clear. He wore a stovepipe hat which had become his trademark and was dressed entirely in black. Although somewhat bent he walked easily and gave the impression of great physical strength. Odd as his appearance was in western eyes there was no doubting his 'presence'; he easily dominated any company he found himself in.

At 1300 hours on Saturday, 20 October the Gelderland weighed anchor and got underway. During the preparations for departure tension among the men had risen again and now it reached a peak. Netherlands authorities had been aware of course from the outset that if the British military had wanted to capture Kruger they had had to do so before he crossed into neutral territory. Much as London might have disliked seeing Kruger drum up support for the Boer war effort in Europe the prospect did not warrant exascerbating world opinion further by violating the territorial integrity of Portugal or the Netherlands. Also, Kruger's chances of success were bound to be slight. What country would want to risk hostilities with the British Empire for the sake of two small nations 5000 miles away? For these and other reasons to be mentioned later even Germany, the Boer's loudest champion, had declared its neutrality. Thus from Whitehall's standpoint, the best course of action under the circumstances was to frown, but do nothing. That this position was known to all concerned is shown by the fact that de Landas Wijborgh had constant and amicable contact with his British counterpart, Captain Fisher of the cruiser Magicienne during the Gelderland's stay at Lorenco Marquez. Not having been privy to this information, the crew of the Gelderland may be excused for having eyed the silent British warships uneasily as they slowly 
passed in front of them and for sighing with relief when the first ocean swell lifted the ship's bow and nothing had happened.

Throughout the departure the President and his party had remained on deck in full view of watchers aboard the British squadron, many of whom were seen to be using binoculars to get a better look. Once outside the bay the ocean swell quickly wiped out the party except for the president himself. He stayed on deck for a long time gazing pensively at the receding coastline. His thoughts must have been sombre ones. Whatever face was put on his departure, the salient facts were that his country had been overrun and that he had to flee to avoid capture by the enemy. He must have wondered whether he would ever see his country again.

As far as the crew of the Gelderland was concerned, after the danger of attack, imaginary as it may have been, was behind them there was a temporary sense of letdown. Soon however the day-to-day routine of shipboard life took over and the events in Delagoa Bay receded in memory. In time speculation arose about what might happen at various British strongpoints the ship would have to pass before reaching Marseilles, but for the time being the voyage was uneventful.

It quickly became apparent that the president followed an unvarying daily routine. He would rise at dawn, eat breakfast in his stateroom, and appear on deck by 0700 . A small table and a few chairs had been set up for him on the aft deck and he would spend the better part of the day there. During the morning hours he usually worked on papers for some time together with Eloff. The rest of the day he sat mostly in his rattan chair smoking his short-stemmed pipe apparently lost in thought. He prayed aloud in his rumbling bass voice before and after each meal and went to bed shortly after the evening meal. He did not drink and discouraged the habit in the others of his party. However, only Happé was forbidden outright to use alcohol. Since the ship's complement received a daily liquor ration and there were no strict regulations about drinking after hours, Happé - no teetotaler - found himself constantly tempted. When he finally succumbed and had a nip he quickly got himself in trouble. When the president called for him shortly afterwards he immediately smelled what had happened. Saying 'Je hebt drank gebruikt' (you have used liquor), the old Boer in vexation grabbed Happé's hand and squeezed until the man yelled with pain. There is no record of the valet having made the same mistake twice.
One morning Kruger surprised everyone by coming on deck in white shoes, a visored cap, and dark glasses, all worn with the customary black suit. The accoutrements were the only concession he made to the heat and bright sun of the Indian Ocean. Kruger discouraged company and, as said spent most of the daylight hours on the aft deck. This unvarying routine caused a few moments of panic when he decided one day, on the spur of the moment, to take the commandant up on his standing invitation to join him on the bridge. His unexplained absence from his customary seat resulted in a frantic search of his suite. Just as it seemed imperative to give the alarm Kruger was seen returning from the bridge in the company of the commandant.

The president's presence aboard had a sobering effect on the usually fun loving Dutch sailors. Therefore, when the opportunity presented itself to let at least some of them blow off a little steam the commandant decided to accept the chance. On 26 October the ship reached Dar-es-Salaam in what was then known as the German East African Protectorate. This ill-defined and largely unexplored territory came technically under the suzerainty of the Sultan of Muscat. Having too many enemies at home the Sultan had moved his domicile to Zanzibar from where he had leased the territory to the German government. The Germans, forever neat, had put their stamp on the town by actually laying out European-style housing areas with tree-shaded streets. The town had a small Army garrison and a German naval vessel lay at anchor in the river. The German influence did not extend to the business world, that is not to the local market for food and other daily necessities; that part of the economy remained firmly in the hands of Arabs. Procuring bunker coal proved to be no problem, but buying fresh meat and produce was another matter as the Gelderland's purchasing agent and his men were to find out. The prices quoted by the Arab merchants were uniformly outrageous and Dutch tempers were beginning to flare when someone suggested time out for a cold beer at the nearby hotel 'Zur Kroenen'. This proved to be a fortuitous decision for although the beer was expensive the men learned from the bar-tender something about the rules and etiquette of the Arab marketplace. They were taught for instance that an asking price was simply meant as an opening gambit in the bargaining process. No merchant expected to get the asking price and would even look down on anyone so foolish as to pay it. Refreshed by the beer and armed with their new-found knowledge the men returned to the 
fray. The bartender had been right, some brisk bargaining resulted in prices they could live with. Back aboard ship the men were asked what language they had used in bargaining. None of them spoke Arabic and the dealers certainly had not spoken Dutch. Obviously the process had taken place mostly in sign language plus scribbled figures.

Meanwhile the commandant of the German cruiser 3rd class Condor in Dar-es-Salaam had invited the staff and subalterns of the Gelderland for a party aboard his ship the next evening. The invitation had no sooner been accepted when a similar one arrived from the garrison ashore. In the interest of international relations and German inter-service amity the commandant accepted the second invitation also. He then arranged for the officers to meet aboard the Condor while he left it up to the subalterns to work out the logistics of their two separate parties. Negotiations led to an agreement whereby the Gelderland noncoms would first attend the party on the Condor and then meet their Army hosts ashore by midevening. When party time came around all but the few unfortunates who had drawn duty, and the lower ratings who were not permitted ashore, rowed over to the German ship. The Condor's Executive Officer gave a short welcoming speech, tasted the beer, and then disappeared in the direction of the wardroom. The ship's noncoms had done themselves proud. The well of the ship was decked with bunting and there were long tables with kegs of lager beer in ice and plenty of food. With all the ingredients for a party at hand the only thing needed was something to get things started. The ship's band provided the catalyst - even then really popular songs tended to be international - and soon the ice was broken and the language difficulties overcome or forgotten. When time came for the guests to leave for the party ashore things had become sufficiently jolly for everyone to agree that it would be a shame to break up such a lovely party. It was decided therefore to send emissaries ashore with the proposal that the Condor noncoms be permitted to join the Army party. To sweeten the deal the Condor's men offered to bring their own beer as well as their band. The proposal was accepted and to add a touch of class to the occasion a small tug was brought in to tow the liberty boats ashore and bring them back again later. Thus no one had to row and the revelers sat back contentedly while the band played away on the stern of the tug. Since all this had taken time and the night was hot the army noncoms had decided to start their own party ahead of the arrival of their guests. Thus, when everyone came together there were few totally sober types around. With no less than three bands playing (two of them were made up of natives under the direction of German Army noncoms) the party now resumed bigger and better than before. The rest of the evening and part of the night passed in a rosy glow. There were a number of attempts at speechmaking, but no one listened. Toasts were another matter, and many of them were made to Kruger and the cause of Boer independence. The party did not break up until the wee hours and probably mostly because exhaustion had begun to set in. When the thought of going back to their ship hit them, some of the men began to worry about what the Officers of the Watch would say. Thus, although not exactly silent, the celebrants arrived back at the anchorage in a somewhat subdued state. As it turned out they need not have worried for the sounds coming from the Condor indicated that the officers party was still going strong. With yells, snatches of songs, and loud goodbyes echoing over the dark waters the men clambered back aboard their respective ships. Miraculously there were no casualties, no one fell overboard and no one landed in the brig for overboisterous behaviour. There is no record of the president's reaction to these goings on, but one may presume that his patience was sorely tried. He himself had declined an invitation from the military governor and had gone to bed at his customary hour. Whatever his feelings at the time and notwithstanding his personal attitude toward drinking, he ordered Happé a few days later to serve all the noncoms a round of beer. The next day found the whole Etat major and all the noncoms nursing a giant hangover. Fortunately the bunkering operation had gone so slowly that departure could be postponed until the next morning.

At 0530, 29 October, the Gelderland left Dar-es-Salaam and turned north once more. Whether disturbing information had been received or the commandant simply felt that the men needed the extra work, there were a number of battle stations calls the next few days. On Monday afternoon, 5 November, the Gelderland entered the harbour of Djibouti for bunkers and stores. As Djibouti was served by mail steamers many of the men found letters from home waiting for them. Almost everyone took advantage of the opportunity to write home and tell the folks about their adventures. Eloff left the ship to take a mail steamer for Marseilles in order to arrange for the reception there of the president and his party. The governor of French Somaliland gave a reception 
and dinner in honour of the president. Kruger declined this invitation also, but did agree to receive visitors. As a result a number of notables visited the ship in the next few days to include the Negus (King) of Abyssinia, and the French ambassador to that country.

The Gelderland departed Djibouti during the afternoon of 9 November entering the Red Sea for the second time. This time temperatures were considerably more moderate and the engine room crew had become better acquainted with its job. There were no incidents therefore. There were signs on all hands that the Gelderland and its passenger had become the centre of world attention. Passing ships gave salutes and some, like the Kronprinz of the German East Africa Line, dropped anchor to let her pass ahead. At Suez hundreds of small craft swarmed around the ship loaded with people hoping to catch a glimpse of the president. Guards had to be posted to keep people from clambering aboard. On 15 November Port Said was reached where, ironically, the Gelderland had to moor virtually alongside a British destroyer, the crew of which elaborately ignored her presence. The Netherlands consul brought word that there were rumours of unsavoury characters having come into town from hired assassins to anarchists. Whatever the commandant may have thought of this lurid information in private he took no chances and doubled the Marine guard. Even without assassins abroad the guards had their hands full keeping the hordes of reporters and the plain curious at bay.

In order to quell a persistent rumour that the ship would return to the Netherlands after bringing the president to Marseilles the commandant let it be known that the Gelderland would turn around immediately at Marseilles and resume its voyage to the east Indies. He also promised the lower ratings liberty when the ship stopped at Algiers again. There was some grumbling in the ranks about the announcement, but most men agreed that having one's tour of tropical duty reduced by three months was not a bad thing.

The Gelderland left Port Said the evening of November the 15th after taking on 600 tons of coal in $7 \frac{1}{2}$ hours, a record up to that time. After the heat of the Red Sea the Mediterranean weather felt positively cold. Thus the tropical white uniforms were stored away again and everyone went back into blues. Three days out of Port Said the Gelderland passed a 5 ship British squadron travelling east. As before no signals were exchanged. As the British ships fell astern and finally passed over the horizon it seemed to those around him that the president brightened visibly. $\mathrm{Had}$ he feared up to that time that the British might try and intercept him? Whatever lay behind the change he was clearly more animated, began to speak with some of the crew members, and even agreed to a photo session the next morning. After a stormy day and night the ship arrived off the port of Marseilles early in the morning of November the 22nd. The pilot cutter brought a deputation of Transvaal officials, to include Dr. Leijds, the president's advisor on foreign affairs. Mrs. Heijmans and Mrs. Eloff also came aboard, which resulted in a rather touching reunion of the old man and his 'little' granddaughter.

At 0910 the Gelderland entered the La Joliette section of the port of Marseilles. Like all of the harbour of Marseilles the La Joliette basin is rather confined, and on that November morning its quays were rimmed by a solid wall of cheering and flag waving people while hundreds of small craft swarmed around the ship. At a quarter to eleven the president appeared on the deck where he gave a speech of thanks to the assembled staff. After shaking hands with the commandant Kruger walked over to the accommodation ladder where the captain's gig waited to take him ashore. At that point the crowd caught sight of him and a thunderous roar went up which he acknowledged with a tip of the famous stove pipe hat. As the boat left the side of the ship a band aboard one of the craft that milled around struck up the Transvaal National Anthem. When, after a few notes, the crowd recognized the tune the roar reached a crescendo. Reverberating from surrounding buildings the roar drowned out the music and created a vortex into which everything else seemed to be swallowed up. From the deck of their ship the men of the Gelderland watched as the oars rose and fell rhythmically drawing the craft steadily closer to a point on the quay where masses of flags and banners indicated the location of the reception committee. Stepping ashore with the ease of a man far younger than his years Kruger spurned a proffered chair, listened to the mayor's welcoming speech and gave a short speech of thanks in return. The speechmaking done the party entered open carriages for the trip to the Grand Hotel de Noailles for its first night's stay on French soil. Meanwhile, as the president's party was swallowed up in the masses of people on the quay the Gelderland quietly got underway again to resume its interrupted voyage to the East Indies. 


\section{EPILOGUE}

Kruger's tumultuous reception at Marseilles was repeated at every stop along the way to Paris. Travelling by slow train he stopped for public ovations and official speeches at Tarascon, Avignon, Valence, Macon, Chalon sur Saône, and Lyon. At Dijon he stayed the night arriving in Paris on 24 November. Here the difference between public acclaim and official attitudes based on the realities of international relations became evident. The reception President Loubet had prepared for him was everything he could possibly have asked for. He received the full treatment usually reserved for crowned heads of state, i.e., Cuirassiers, the Garde Republicaine, an open carriage parade, and formal receptions. However, when it came to concrete proposals for assistance to the Boer republics the French president declared himself powerless, as in a real sense he was of course. Kruger pressed his host hard, but Loubet did not see how he could help except by submitting the dispute to the International Tribunal at The Hague, a gesture which both men knew to be meaningless at that juncture. Official Paris sighed with relief when the stubborn old man left for Germany for talks with the Kaiser. Germany's Kaiser Wilhelm II had been an enthusiastic supporter of the Boer cause in the past and Dr. Leijds had reported finding willing ears in the Wilhelmstrasse. Kruger must therefore have entered some hopes for meaningful support from that quarter. Instead he was rebuffed rather rudely. While at Bonn he received a message from the Kaiser pleading a previous engagement - a hunting engagement no less - which prevented him from meeting with the Boer president. Neither Kruger nor the world at large was aware at that time that two years before Great Britain and Germany had signed a treaty, ostensibly about lending money to Portugal to tide it over economic difficulties, the secret protocol to which effectively defined the spheres of influence of the two countries in central and south Africa. It had been in part the Kaiser's chagrin at the British headstart in the African colonial sweepstakes that had caused him to side with the Boers, while it had been in part alarm at German demarches in East and Southwest Africa that had caused London to force the issue in South Africa. Even though the Kaiser may not have been entirely happy with the de facto result of the 1898 treaty he could not now very well support the Boers against Great Britain. Hence the rebuff to Kruger. There has also been some speculation that the scolding Wilhelm had received from his grandmother, Queen Victoria, over his effusively congratulatory telegram to Kruger after the abortive 1895 Jameson Raid had something to do with the Kaiser's action. The point is moot while the fact is simply that the Kaiser refused to see Kruger. Kruger must have realized then that all was lost. He will have been realistic enough not to expect too much, but he may certainly have hoped for the Kaiser to use his good offices to induce the British to renew negotiations rather than to continue insisting on unconditional surrender. In this matter the Kaiser and Kruger would certainly have had world opinion on their side. In England itself there were those who strongly condemned the government's policy in South Africa and even Kitchener, the country's commander in the area, was to call for negotiations a little later. All hopes along these lines were now dashed. The Kaiser's rebuff cruelly exposed Kruger's status as that of an ex-president of a conquered nation, a political refugee.

From Bonn Kruger went to The Hague where he had dinner with Queen Wilhelmina in private. The 20 years old Dutch queen had done all she could by rescuing him from Lorenço Marquez, risking thereby the enmity of her -country's powerful neighbour across the North Sea. More she could not do. From The Hague Kruger travelled to Switzerland and the French Mediterranean coast, living mostly in seclusion from then on. Life must have lost all meaning for him. Reports from home indicated that the war was irretrievably lost. Even the death on 26 March 1902 of his archenemy Rhodes must have seemed devoid of significance. On 31 May 1902 General Botha signed the Treaty of Vereeniging ending the agony, but not before the Boers had seen 29000 of their compatriots, mostly women and children, die in Kitchener's concentration camps. Kruger lived another two years, passing away at Clarens, Switzerland on 14 July 1904 . No better testimony to the agony of Kruger's last years as an exile can be found than in the following poignant lines from his last letter to Botha written just a few weeks before his death:

II have learned to accept the bitter thought of death as a lone exile in a foreign land, far from my kith and kin whose faces I am not likely to see again; far from the soil of Africa, upon which I am not likely ever to set foot again; far from the country to which I devoted my whole life. ..'

As for the Gelderland, she was rammed by the British freighter Peterson on her way to Port Said, 
possibly on purpose. After a long, but uneventful peacetime career she was decommissioned in 1940. The German invaders of the Netherlands converted her into a Flakschiff or anti-aircraft artillery platform and renamed her the Niobe. Sunk by Russian aircraft in the Gulf of Finland in July 1944 she was refloated by the Finns in 1947 , but abandoned by the Netherlands government. A melancholy end to a career that had started with such éclat.

- Johannes Vrugtman is a retired United States civil servant.

\section{A Few Notes on Sources}

The idea for the article came from reading a diary the writer's father had kept while serving as a subaltern aboard the Gelderland during its historic maiden voyage. Information on President Kruger's actions while abroad the Gelderland comes from the above source. The use of the diary resulted in an article written from a crew member's viewpoint with the writer's commentary placing it in historic perspective.

For lack of detailed information or to help the narrative along, some minor liberties have been taken in the description of a few events such as the commissioning ceremonies and the party at Dar-es-Salaam. However, in all other respects the article follows standard historica sources. The interpretation given to the historical events described is the writer's own.

The technical data on the Gelderland were obtained from the Historical Department of the Netherlands Ministry of Defence and from the Netherlands Maritime Museum in Amsterdam. The first named agency was also the source of a copy of the Captain de Landas Wijborgh's official voyage report.

Information on the 1898 Anglo-German Treaty with its two secret addenda was derived from Volume II of the 1928 condensed edition of German foreign policy papers edited by A. MendelsohnBartholdy and Friedrich Thimme. (Die Auswärtige Politik des Deutschen Reiches 1871-1914. Deutsche Verlagsgesellschaft fur Politik und Geschichte m.b.H., Berlin, 1928. Kapital 24.) 